\title{
Aryl hydrocarbon hydroxylase activity in type II alveolar lung cells
}

\author{
R.W. Teel and W.H.J. Douglas \\ Department of Physiology and Pharmacology, School of Medicine, Loma Linda University, Loma Linda (CA 92350) and \\ Department of Anatomy, Tufts University, Boston (MA 02111, USA), 2 April 1979
}

Summary. Type II alveolar lung cells metabolize polycyclic aromatic hydrocarbons as indicated by measurements of aryl hydrocarbon hydroxylase activity and binding of tritium labeled benzo(a)pyrene to nuclear and cytoplasmic components.

Various polycyclic aromatic hydrocarbons (PAH) contaminate the environment and are implicated in the human cancer problem. They require metabolic activation through at least 2 enzyme systems ${ }^{2,3}$. Metabolites may interact with cellular macromolecules to induce mutagenesis, carcinogenesis and toxicity ${ }^{4}$. The lung is directly exposed to PAH and is thus recognized as a primary target for PAH induced carcinogenesis ${ }^{5}$. In this study we show evidence for PAH metabolism in clonally derived type II alveolar lung cells of the rat $^{6}$.

Materials and methods. Type II alveolar pneumonocytes (L-2) were maintained in vitro in Ham's modified F12K medium supplemented with $10 \%$ fetal bovine serum at $37^{\circ} \mathrm{C}$ in a humidified atmosphere of $5 \% \mathrm{Co}_{2}$ in air. L-2 cells at population doubling levels 26 and 27 were grown to confluency and fed fresh medium to which either benzo(a)pyrene (BP), 9,10-dimethyl 1,2-benzanthracene or 3 -methylcholanthrene at a final concentration of $2 \mu \mathrm{g} / \mathrm{ml}$ was added. After $24 \mathrm{~h}$ cells were washed with buffered saline and aryl hydrocarbon hydroxylase (AHH) activity was determined by fluorometric measurements of water soluble metabolites as described ${ }^{7,8}$. AHH activity was expressed as units/ $\mu \mathrm{g}$ DNA where 1 unit was defined as that amount of activity producing hydroxylated products equal in fluorescence to 1 pmole of 3-hydroxybenzo(a)pyrene ${ }^{7}$. DNA was quantitated as described ${ }^{8}$. L-2 cells exposed for $24 \mathrm{~h}$ to $3 \mathrm{H}-\mathrm{BP}$ (sp. act. $25.2 \mathrm{Ci} / \mathrm{mM}$ ) at a final concentration of $2 \mu \mathrm{Ci} / \mathrm{ml}$ were washed and homogenized to yield free intact nuclei. Nuclei were solubilized and aliquots counted in $10 \mathrm{ml}$ scintillant in a Beckman LS-230 liquid scintillation counter. Bound label was expressed as cpm per $\mu \mathrm{g}$ DNA. Unbound label was removed from the cytoplas-

Table 1. Aryl hydrocarbon hydroxylase activity in type II alveolar pneumonocytes clonally derived from adult rat lung ${ }^{6}$

\begin{tabular}{ll}
\hline PAH compound tested & $\begin{array}{l}\text { AAH activity } \\
\text { Mean SEM }\end{array}$ \\
\hline Benzo(a)pyrene & $7.85 \pm 0.23$ \\
9,10-dimethyl 1,2-benzanthracene & $4.1 \pm 0.1$ \\
3-Methylcholanthrene & $0.59 \pm 0.12$ \\
Controls (No PAH) & $0.21 \pm 0.022$
\end{tabular}

L-2 cells were exposed to one of 3 polycyclic aromatic hydrocarbons for $24 \mathrm{~h}$ at a concentration of $2 \mu \mathrm{g} / \mathrm{ml}$ culture medium. Fluorescence of water-soluble product was determined and activity expressed as units $/ \mu \mathrm{g}$ DNA. Assays were run in triplicate.

Table 2. Binding of $3 \mathrm{H}-\mathrm{BP}$ to nuclear and cytoplasmic fractions of homogenized L-2 cells

\begin{tabular}{ll}
\hline Cellular Fraction & cpm \\
& Mean SEM \\
\hline Nuclear & $674 \pm 28$ \\
Cytoplasmic & $99.8 \pm 3.34$ \\
\hline
\end{tabular}

Samples were counted in quadruplicate in a Beckman LS-230 liquid scintillation counter with a tritium counting efficiency of $60 \%$. Data are expressed as $\mathrm{cpm} / \mu \mathrm{g}$ DNA in the nuclear fraction and $\mathrm{cpm} / \mu \mathrm{g}$ protein in the cytoplasmic fraction. mic fraction as described ${ }^{9}$. Aliquots were counted and metabolite binding expressed as $\mathrm{cpm} / \mu \mathrm{g}$ protein. Protein was quantitated according to described methods ${ }^{10}$.

Results and discussion. L-2 cells used in these studies possess osmiophilic lamellar bodies in their cytoplasm ${ }^{6}$ and are enriched in enzymes involved in the synthesis of phosphatidylcholine ${ }^{11}$. These cells thus possess properties of pulmonary surfactant producing type II alveolar pneumonocytes. Data reported here suggest that L-2 cells contain aryl hydrocarbon hydroxylase and therefore have the capacity to metabolize polycyclic aromatic hydrocarbons. The results of fluorescence measurements of water soluble product following a $24 \mathrm{~h}$ exposure to PAH compounds are shown in table 1 . Benzo(a)pyrene (BP) induces about twice the AHH activity of dimethylbenzanthracene and 13 times that induced by 3-methylcholanthrene. A similar response was observed in mouse $3 \mathrm{~T} 3$ cells $^{12}$.

A preferential binding of $3 \mathrm{H}-\mathrm{BP}$ metabolites to the nuclear fraction of homogenized L-2 cells is indicated in table 2. The target sites for ultimate carcinogen action are thought to involve nuclear macromolecules ${ }^{13}$. Binding of $3 \mathrm{H}-\mathrm{BP}$ metabolites to DNA, RNA, and nuclear proteins has been described $^{14}$. Current studies are underway to examine the binding of $3 \mathrm{H}-\mathrm{BP}$ to specific nuclear macromolecules in L-2 cells.

It is not known whether binding of BP to cytoplasmic receptors is a prerequisite to nuclear binding but it has been suggested that cytoplasmic protein receptors could function to facilitate carcinogen transport to nuclear receptor sites ${ }^{9}$. Interaction with critical macromolecules could then initiate the cellular events associated with transformation.

In conclusion these studies indicate that type II alveolar lung cells possess the enzyme machinery for PAH metabolism and that nuclear and cytoplasmic receptors bind BP. The relationship of PAH metabolism in type II cells to lung carcinogenesis is yet to be illucidated.

1 M. Pike, R. Gordon, B. Henderson, H. Bench and J. Soohosp, in: Persons at High Risk of Cancer, p.225. Ed. J.F. Fraumeni, Jr. Academic Press, New York 1975.

2 A. Borgen, H. Darvey, N. Castagnoli, T. Crocker, R. Rasmussen and I. Wang, J. med. Chem. 16, 502 (1973).

3 S. Yang, D. McCourt, P. Roller and H. Gelboin, Proc. nat. Acad. Sci. 73, 2594 (1976)

4 W. Levin, A. Wood, H. Yagi, P. Dansette, D. Jerina and A. Conney, Proc. nat. Acad. Sci. 73, 243 (1976)

5 S. Hundley and R. Freudenthal, Cancer Res. 37, 3120 (1977).

6 W.H. J. Douglas and M. Kaighn, In Vitro 10, 230 (1974).

7 D. Nebert and H. Gelboin, J. biol. Chem. 243, 6242 (1968).

8 H. Gurtoo, J. Minowada, B. Paigen, N. Parker and N. Thompson, J. nat. Cancer Inst. 59, 787 (1977).

9 K. Ekelman and G. Milo, Cancer Res. 38, 3026 (1978)

10 G. Toennies and F. Feng, Analyt. Biochem. 11, 411 (1965).

11 W.H.J. Douglas, P. Del Vecchio, R. Teel, R. Jones and P. Farrell, in: Lung Cells in Disease, p. 53. Ed. A. Bouhuys. North-Holland Biomedical Press, Amsterdam 1976.

12 M. Bittner and R. Ruddon, Molec. Pharm. 12, 966 (1976).

13 C. Heidelberger, A. Rev. Biochem. 44, 79 (1975).

14 J. Pezzuto, M. Lea and C. Yang, Cancer Res. 36, 3647 (1976). 